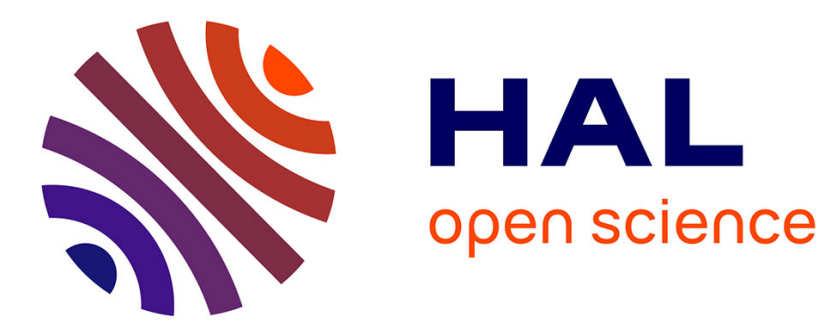

\title{
Evaluation of daily intake of PCDD/Fs and indicator PCBs in formula-fed Spanish children
}

\author{
Susana Lorán, Pilar Conchello, Susana Bayarri, Antonio Herrera
}

\section{To cite this version:}

Susana Lorán, Pilar Conchello, Susana Bayarri, Antonio Herrera. Evaluation of daily intake of PCDD/Fs and indicator PCBs in formula-fed Spanish children. Food Additives and Contaminants, 2009, 26 (10), pp.1421-1431. 10.1080/02652030903100034 . hal-00573902

\section{HAL Id: hal-00573902 \\ https://hal.science/hal-00573902}

Submitted on 5 Mar 2011

HAL is a multi-disciplinary open access archive for the deposit and dissemination of scientific research documents, whether they are published or not. The documents may come from teaching and research institutions in France or abroad, or from public or private research centers.
L'archive ouverte pluridisciplinaire HAL, est destinée au dépôt et à la diffusion de documents scientifiques de niveau recherche, publiés ou non, émanant des établissements d'enseignement et de recherche français ou étrangers, des laboratoires publics ou privés. 


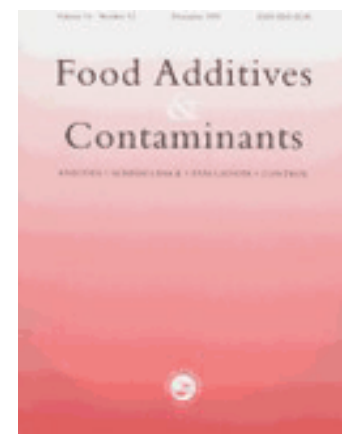

\section{Evaluation of daily intake of PCDD/Fs and indicator PCBs in formula-fed Spanish children}

\begin{tabular}{|r|l|}
\hline Journal: & Food Additives and Contaminants \\
\hline Manuscript ID: & TFAC-2009-049.R1 \\
\hline Manuscript Type: & Original Research Paper \\
\hline Author: & $29-$ May-2009 \\
\hline Complete List of Authors: & $\begin{array}{l}\text { Lorán, Susana; Veterinary Faculty, University of Zaragoza, } \\
\text { Department of Animal Production and Food Science } \\
\text { Conchello, Pilar; Veterinary Faculty, University of Zaragoza, } \\
\text { Department of Animal Production and Food Science } \\
\text { Bayarri, Susana; Veterinary Faculty, University of Zaragoza, } \\
\text { Department of Animal Production and Food Science } \\
\text { HERRERA, ANTONIO; Veterinary Faculty, University of Zaragoza, } \\
\text { Department of Animal Production and Food Science }\end{array}$ \\
\hline Methods/Techniques: & Exposure assessment \\
\hline Additives/Contaminants: & Dioxins - TEQs, PCBs \\
\hline Food Types: & Infant formulae \\
\hline & \\
\hline
\end{tabular}

\section{SCHOLARONE Manuscripts}


Evaluation of daily intake of PCDD/Fs and indicator PCBs in formula-

\title{
fed Spanish children
}

\author{
Susana Lorán, Pilar Conchello, Susana Bayarri, Antonio Herrera
}

University of Zaragoza, Department of Animal Production and Food Science, Veterinary Faculty, C/ Miguel Servet, 177, 50013 Zaragoza, Spain

\begin{abstract}
Human exposure to polychlorinated dibenzo-p-dioxins (PCDDs), dibenzofurans (PCDFs) and polychlorinated biphenyls (PCBs) occurs predominantly via food intake. In this study, the exposure assessment of these contaminants has been estimated for infant formula fed children up to one year of age. PCDD/Fs concentration in the infant formulae was low, ranging between 0.09 and $0.17 \mathrm{pg}$ WHO-TEQ $\mathrm{g}^{-1}$ fat and between 0.30 and $0.46 \mathrm{pg}$ WHO-TEQ $\mathrm{g}^{-1}$ fat when results were calculated with the lower and medium bound values, respectively. Indicator PCBs contamination level were below 1 $\mathrm{ng} \mathrm{g}^{-1}$ fat in all cases. Thus, the estimated PCDD/Fs and indicator PCBs daily intake of infants has been assessed taking into account the above mentioned contamination levels as well as different scenarios of body weight and food consumption data for babies aged 0 to 12 months. The results vary in the different scenarios considered, but on the whole, the daily estimated dioxin and indicator PCBs intake of the average infant population due to the consumption of infant formulae does not exceed the tolerable daily intake (TDI) of 2 pg WHO-TEQ kg ${ }^{-1}$ b.w. day ${ }^{-1}$ (SCF, 2001) nor the threshold of $10 \mathrm{ng} \mathrm{kg}^{-1}$
\end{abstract}




\author{
b.w. day ${ }^{-1}$, value proposed by the Dutch National Institute of Health and Environment \\ (RIVM), respectively (Baars et al. 2001).
}

Keywords: PCDD/Fs, PCBs, infant formulae, dietary intake, children, exposure assessment

\title{
Introduction
}

Organochlorine compounds such as polychlorinated dibenzo- $p$-dioxins (PCDDs), polychlorinated dibenzofurans (PCDFs) and polychlorinated biphenyls (PCBs) represent a class of widely distributed environmental contaminants which exhibit a potential risk for human health. Dioxins are mainly by-products of industrial processes, being waste incineration, especially if combustion is incomplete, the largest contributor of dioxin release into the environment. But dioxins can also result from natural processes like volcanic eruptions and forest fires (SCF, 2001; Baars et al. 2004). Unlike dioxins, PCB mixtures were commercially produced for about five decades for its use in a wide scale of applications such as electronic appliances, heat transfer systems, hydraulic fluids and many other different industrial purposes (Baars et al. 2004; EFSA, 2005). Although PCB production was banned in industrialized countries in the 1970s, residues can still enter the environment due to their lipophilic nature, persistence and ample use in the past.

Previous reports have revealed that dietary intake is the main route $(>90 \%)$ for non-occupational human exposure to these toxicants; foods of animal origin usually being the main contributors of the total intake (Baars et al. 2004; EFSA, 2005). In many countries concentrations of PCDD/Fs and PCBs have regularly been monitored in a great variety of food matrices. Available data indicate a reduction in the past decades 
due to measures implemented to control the emissions of these compounds and so exposures and body burden are lower now than years before (Llobet et al. 2008). Yet, despite these extensive efforts, foods are still contaminated (Fernández et al., 2004; EFSA, 2005; Gómara et al., 2005; Bordajandi et al., 2006; Bocio et al. 2007; Llobet et al. 2008).

Like adults, children's primary source of exposure to these contaminants is food. Exposure assessments of $\mathrm{PCDD} / \mathrm{Fs}$ and $\mathrm{PCBs}$ for the general population have been made in several industrialized countries but most of them have no consideration of young children (Lázaro et al. 2002; Tard et al. 2007), although many studies have also been made for breast-fed infants (Focant et al. 2002; Hsu et al. 2007; Szyrwińska and Lulek, 2007). This is probably due to the fact that as these compounds accumulate in fatty tissues, breast milk has been one of the preferred matrices to evaluate human background contamination. Additionally, there has been a particular concern in recent years about the characterization of breast-fed exposure to these substances and the associated potential health risk.

Infant formulae are an alternative to human milk which is recommended for infants who are not breast-fed or during the weaning period and they can play an important role in the infant diet. However, only a few reports are available on the PCDD/Fs and PCB levels in infant formulae, usually showing low concentrations of these pollutants (Ramos et al. 1998; FSA UK, 2004; Hsu et al. 2007).

Related to the daily PCDD/Fs intake, World Health Organization (WHO) recommended in 1998 a tolerable daily intake (TDI) of PCDD/F in a range of 1 to $4 \mathrm{pg}$ WHO-TEQ kg ${ }^{-1}$ b.w.day ${ }^{-1}$ (WHO, 1998). In later revisions, a tolerable weekly intake of 14 pg WHO-TEQ kg ${ }^{-1}$ b.w.week ${ }^{-1}$ (SCF 2001) and a tolerable monthly intake of $70 \mathrm{pg}$ WHO-TEQ $\mathrm{kg}^{-1}$ b.w.month ${ }^{-1}$ (JECFA 2002) have been established. For practical 
reasons these maximum intakes can be handled as a tolerable daily intake of 2 pg TEQ per kg b.w. per day. In addition, the European Commission recently set maximum levels of PCDD/Fs and dioxin-like PCBs permitted in food (EC, 2006). For non-dioxin like PCBs neither a tolerable daily intake nor a maximum limit in feed and food have been established for these compounds in the European Union, which is why some countries have established reference values that can be used in order to evaluate food contamination or human exposure to these compounds.

Current PCDD/Fs exposure of breast-fed infants is about 13 pg WHO-TEQ kg-1 b.w. day $^{-1}$ for one year old children in Taiwan (Hsu et al. 2007), 51 pg WHO-TEQ kg ${ }^{-1}$ b.w. day $^{-1}$ in Portugal (Reis et al. 2002) or 76 pg WHO-TEQ kg ${ }^{-1}$ b.w. day ${ }^{-1}$ in Belgium (Focant et al. 2002). Mean exposure to the seven indicator PCBs has been calculated between 364 and $375 \mathrm{ng} \mathrm{kg}^{-1}$ b.w. day ${ }^{-1}$ for first and second breast-fed infants in Poland, respectively (Szyrwińska and Lulek, 2007), and $1249 \mathrm{ng} \mathrm{kg}^{-1}$ b.w. day ${ }^{-1}$ in the European Union (EFSA, 2005). There are few surveys which have studied the exposure of non breast-fed children to these pollutants revealing PCDD/Fs intake levels of $2.1 \mathrm{pg}$ WHOTEQ kg ${ }^{-1}$ b.w. day ${ }^{-1}$ in one year old children (Hsu et al. 2007) or varying between < 0.01 and $0.3 \mathrm{pg}$ WHO-TEQ $\mathrm{kg}^{-1}$ b.w. day ${ }^{-1}$ in 6 month old babies and between $<0.01$ and $0.2 \mathrm{pg}$ WHO-TEQ/kg. b.w./day in 9 and 12 month old English children (FSA UK, 2004).

One of the main difficulties when comparing and evaluating infant babies dietary exposure to these compounds is the children's different ages, body weights and food consumption data used in these estimations, which are not consistent in the published literature. Milk consumption intakes between 600 and $800 \mathrm{ml} /$ day have been considered for 5-7 kg of body weight children (Focant et al. 2002; Reis et al. 2002; EFSA, 2005). In Taiwan, PCDD/Fs dietary intake was estimated for breast and non- 
breast-fed children by using body weight and food consumption data reported by the Taiwanese Department of Health (Hsu et al. 2007). However, this information is not available in many countries. Concerning this point, it is important to mention the EuroGrowth study which is a multi-center, longitudinal cohort study performed in different European regions. The main objectives of this study were to evaluate: a) the longitudinal growth patterns of European children and to develop reference growth charts, b) the dietary habits of European infants and toddlers and c) the influence of nutritional, socioeconomic and geographical factors on growth and health (Haschke and van't Hof, 2000; van't Hof et al. 2000). In this survey, the patterns of milk and food intake in infants from birth to age 36 month were evaluated (Freeman et al. 2000; Haschke et al. 2000a).

When estimating the dietary exposure to potential dangerous substances contained in commercial infant food we should also consider the DONALD study (Dortmund Nutritional and Anthropometrical Longitudinally Designed). This is a longitudinal study collecting detailed data on diet, growth, development and metabolism between infancy and adulthood in Germany. As a part of this study dietary records from 3-, 6-, 9 and 12-month old infants regarding consumption of commercial infant food were evaluated (Kersting et al. 1998).

The main goal of the present study is to estimate the dietary intake of PCDD/Fs and indicator PCBs of Spanish infant babies up to one year of age through the consumption of commercial infant formulae. In so doing we have analyzed the presence of these contaminants in a number of samples of initial, follow-on and lactose-free formulae. Thus, a congener-specific analysis of the 17 toxic PCDD/Fs congeners and the seven indicator PCBs (PCB 28, 52, 101, 118, 138, 153 and 180) has been performed. Estimated intakes have been calculated by using different scenarios of body 
weight and food consumption data. The present study focus on the complexity of finding those suitable referential values as well as on the different estimated intake values of these pollutants depending on the scenarios considered. This survey is one of the scarce studies in which the exposure of formula-fed children to these pollutants is assessed.

\section{Materials and Methods}

Sampling collection

Samples of infant formulae were acquired from local markets, big supermarkets and pharmacies in Zaragoza (Spain) between 2004 and 2005. Trade marks were selected among the most popular in Spain. A total of 70 samples (5 different batches from the same manufacturer) was studied. Infant formulae were divided in three groups, 25 infant formula, 25 follow-on formula and 20 special lactose-free formulas. Infant formulae are those for children from 0 to 6 months of age and follow-on formulas are for infants 6 months and older. Among special formulae, lactose-free formulas are specially adapted to children with lactose intolerance. These commercial infant foods contain skimmed cow milk and mixtures of vegetable oils which are added to these products in order to reach the nutrient requirements for children at this age.

As for the sample preparation, an aggregate sample $(1 \mathrm{~kg})$ was made by mixing proportional pooled samples of 5 different batches from the same commercial trade. Finally, 14 analytical samples were made up, 5 samples of infant formula, 5 samples of follow-on formula and 4 samples of special lactose-free formulas.

Analytical procedure 
The methodology used for PCDD/Fs analysis has been described in detail elsewhere (Lorán et al. 2007). In brief, about 20 grams of the analytical samples were mixed with sodium sulphate anhydrous and extracted with acetone-n-hexane $(1: 1, \mathrm{v} / \mathrm{v})$ in an automated Soxhlet extractor (Soxtec System®, Foss Tecator Cat. No. 1045 HT2, Höganäs, Sweden). For identification and quantification, samples were spiked with ${ }^{13} \mathrm{C}_{12}-\mathrm{PCDD} / \mathrm{Fs}$ labelled internal standard prior to extraction. Each extract was purified in a sequence that comprises purification on a column with sodium sulphate and diatomaceous earth (Isolute ${ }^{8}$ ) with sulphuric acid and then by using a multilayer chromatography column (with sodium sulfate anhydrous, silica gel, a mixture of sodium sulphate and sodium hydrogen carbonate, diatomaceous earth, a mixture of diatomaceous earth and sulfuric acid and a mixture of sodium sulfate and sodium chloride). Finally, the organic extract was subjected to a chromatographic filtration on activated alumina. Fraction containing PCDD/Fs was eluted with dichloromethane. For indicator PCBs analysis, an aliquot of approximately $0.5 \mathrm{~g}$ of the extracted fat was dissolved in hexane and purified on alumina chromatographic column partially deactivated. Elution was carried out with n-hexane. Prior to use, sodium sulphate anhydrous ( $\left.\mathrm{Na}_{2} \mathrm{SO}_{4}\right)$ and sodium sulphate anhydrous mixtures were kept at $120{ }^{\circ} \mathrm{C}$ overnight, and alumina was activated in a furnace at $500{ }^{\circ} \mathrm{C}$ for $12-24$ hours.

Determination of PCDD/Fs and indicator PCBs was carried out after adding the internal standard solution, EPA 1613-ISS (PCDD/Fs) and PCB 209 (indicator PCBs). The eluting fractions containing the compounds of interest were analyzed by high resolution gas chromatography (HRGC) coupled to ion trap mass spectrometry (Varian, Saturn 2000) in the MS/MS mode. This is a three step process where analytes undergo electron ionization and then, a parent ion is selectively stored and fragmented into characteristic product ions through collision induced dissociation (CID). The product 
ions are sequentially ejected from the trap according to their mass/charge $(\mathrm{m} / \mathrm{z})$ ratio and further detected by an electron multiplier.

Chromatographic separation was achieved with a DB-5 fused-silica capillary column (60 $\mathrm{m} \times 0.25 \mathrm{~mm}$ ID, $0.25 \mu \mathrm{m}$ film thickness) with helium as the carrier gas at a linear velocity of $1 \mathrm{ml} / \mathrm{min}$. As for dioxin analysis, injection was carried out in the splitless injection mode $(2 \mu \mathrm{l})$ at a constant temperature of $300{ }^{\circ} \mathrm{C}$ during $1.50 \mathrm{~min}$ with pressure pulse of $45 \mathrm{psi}$ for $1.60 \mathrm{~min}$. The oven temperature program was $120{ }^{\circ} \mathrm{C}$ and held for $2 \mathrm{~min}$, then to $200{ }^{\circ} \mathrm{C}$ (held for $3 \mathrm{~min}$ ) at $30^{\circ} \mathrm{C} / \mathrm{min}$, to $230{ }^{\circ} \mathrm{C}$ (held $15 \mathrm{~min}$ ) at $3{ }^{\circ} \mathrm{C} / \mathrm{min}$ and to $280{ }^{\circ} \mathrm{C}$ (held for $12 \mathrm{~min}$ ) at $5{ }^{\circ} \mathrm{C} / \mathrm{min}$ and finally to $310^{\circ} \mathrm{C} / \mathrm{min}$ ( held for $3 \mathrm{~min})$ at $10^{\circ} \mathrm{C} / \mathrm{min}$. PCBs injection was also made in the splitless injection mode (2 $\mu \mathrm{l})$ at $280{ }^{\circ} \mathrm{C}$ and with pressure pulse of $40 \mathrm{psi}$. The oven temperature program was 65 ${ }^{\circ} \mathrm{C}$ and held for $2 \mathrm{~min}$, then to $235^{\circ} \mathrm{C}$ (held for $10 \mathrm{~min}$ ) at $25^{\circ} \mathrm{C} / \mathrm{min}$, to $310^{\circ} \mathrm{C}$ at 10 ${ }^{\circ} \mathrm{C} / \mathrm{min}$ and finally 4 minutes at $310^{\circ} \mathrm{C}$.

The quantification of PCDD/Fs was carried out by the isotopic dilution method and methodology was validated according to EPA Method 1613 by doing an initial and ongoing precision and recovery study. Instrumental limit of detection (LOD) ranged between $0.05 \mathrm{ng} \mathrm{ml}^{-1}$ for tetra-chloro substituted congeners to $5.0 \mathrm{ng} \mathrm{ml}^{-1}$ for OCDF, depending on the specific congener. PCBs methodology was validated according to international recommendations (EC, 2002) and detection limits for the different PCB congeners were set at $0.5 \mathrm{ng} \mathrm{ml}^{-1}$. In both cases, samples were analyzed in batches constituted by a calibration verification standard solution, a method blank, one spiked sample to check both the ongoing precision and recovery, along with a set of four to six analytical samples. To assess the reliability of our results we have participated in interlaboratory studies related to dioxins and PCBs (Interlaboratory Comparison on 
Dioxins in Food, 2003/2006, Division of Environmental Medicine, Norwegian Institute of Public Health, (Folkehelse, Norway).

As for PCDD/Fs global concentrations, toxic equivalents (TEQ) were calculated using the toxic equivalent factors (TEFs) reported by the World Health Organisation in 1998 (van den Berg et al. 1998). The total concentrations of PCDD/Fs and indicator PCBs have been calculated assuming that non-detected congener concentration is equal to zero (lower bound) and equal to half the limit of detection (medium bound). In order to express the results on a lipid basis, fat lipid content was determined by the Gerber Method modified for powdered milk (Egan et al., 1981).

\section{Intake estimation}

PCDD/Fs and indicator PCBs daily dietary exposure has been calculated multiplying the concentrations of the pollutants found in the samples analyzed by the consumed amount of infant formulae in the different considered periods during the first year of life. In order to calculate the exposure per kilogram of body weight, the estimated daily exposure has been divided by the body weight of children at those ages.

Food consumption data of children up to one year of age have been reviewed in order to measure the intake of these pollutants by Spanish infant babies. Although many nutritional recommendations and studies related with the food consumption habits of the infant babies can be found in the literature (Franch et al. 2001; Bueno et al. 2006) no surveys which quantify the food consumption for Spanish children at these ages have been found. Average daily milk intake has then been obtained from two main sources: the Euro-Growth (Freeman et al. 2000) and the DONALD study (Kersting et al. 1998). Consequently, two different scenarios of exposure have been evaluated in this work. 
In the scenario 1 , in order to estimate the daily exposure to PCDD/Fs and indicator PCBs we have used data from the Euro-Growth study. Is interesting to note that $25 \%$ of these data come from Spanish children. In this case, the food consumption quantities considered correspond to children who are not breast-fed and the volume of milk consumed is for the mean population (Freeman et al. 2000). Body weight data, which has also been obtained from the Euro-Growth study (Haschke et al. 2000b), have been given for the mean population as well as for different percentiles. Some of the extreme body weight values have been considered to estimate the exposure of the highest and lowest exposed children to these compounds, that is the 95 and 5 percentile of body weight respectively. The milk consumption quantities and body weight data used for the intake estimations carried out in the scenario 1 are shown in Table I.

For the scenario 2, food consumption quantities as described in the DONALD Study were used (Table II). These values are given for the mean population but also for those children with different consumption patterns: minimum, maximum and percentiles 5 and 95. However, weight data of infant babies were just described for the mean population (Kersting et al. 1998). These P 95 and P 5 values together with the mean intake of commercial infant food were used in this case for estimating the PCDD/Fs and indicator PCBs dietary intake.

"[Insert Table I about here]"

"[Insert Table II about here]"

Regarding other considerations and according to nutritional recommendations and food consumption habits for infant babies we have considered that initial formula is only consumed by 3-month old children while 6 month children and older drink followon formulas. Besides, milk consumption quantities as described in the Euro-Growth study are referred in volume, however all samples analyzed were powdered infant 
formulae. The transformation of these values given in $\mathrm{ml}$ of milk consumed to grams of powdered infant formulae has been made taking into account the recommendations given in the information nutritional label. In addition, infants' weight data used in these estimations have been given separately for boys and girls in both studies and so we have made in our calculations.

\section{Results and discussion}

The PCDD/Fs (pg WHO-TEQ) concentrations of initial and follow-on formulae have been reported elsewhere (Lorán et al. 2007). Results for the sum of the 17 toxic compounds at the lower bound values are 0.09 pg WHO-TEQ $\mathrm{g}^{-1}$ fat $(0.023 \mathrm{pg}$ WHO-

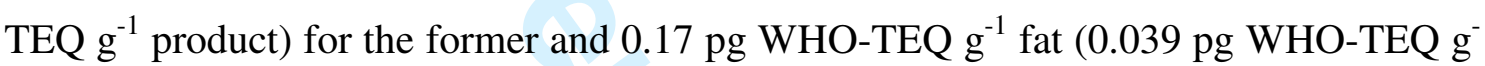
${ }^{1}$ product) for the latest. Besides, 4 composite samples of lactose-free formulae have also been studied with lower bound values of $0.11 \mathrm{pg}$ WHO-TEQ $\mathrm{g}^{-1}$ fat $(0.030 \mathrm{pg}$ WHO-TEQ $\mathrm{g}^{-1}$ product). When infant formulae contamination have been calculated with the medium bound values these concentrations add up to $0.30 \mathrm{pg}$ WHO-TEQ $\mathrm{g}^{-1}$ fat or $0.08 \mathrm{pg}$ WHO-TEQ $\mathrm{g}^{-1}$ product (initial formulae); $0.46 \mathrm{pg}^{\mathrm{W}}$ WO-TEQ $\mathrm{g}^{-1}$ fat or

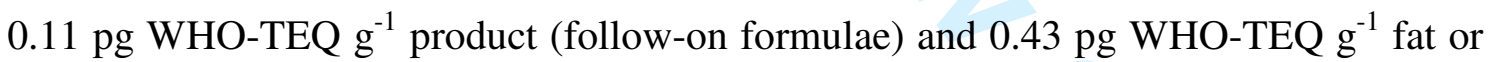
$0.11 \mathrm{pg} \mathrm{WHO}-\mathrm{TEQ} \mathrm{g}^{-1}$ product (lactose-free formulae).

The contamination pattern of the three kind of infant formulae analyzed is represented in Figure 1. The mean concentration of each PCDD/F has been expressed as $\operatorname{pg~g}^{-1}$ fat and calculated as medium bound values.

"[Insert Figure 1 about here]"

The pattern in follow-on and lactose free formulae is characterized by the dominance of PCDFs while PCDDs predominate in initial formulae. For most of the samples, those congeners present in higher concentration are those with a high- 
chlorination degree, especially octachlorinated congeners followed by $1,2,3,6,7,8$ HxCDD, 1,2,3,4,7,8-HxCDD and 1,2,3,4,7,8,9-HpCDF in initial formulae and $1,2,3,4,6,7,8-\mathrm{HpCDD}$ and $1,2,3,4,7,8,9-\mathrm{HpCDF}$ in the others. However, main contributors to the total TEQ values are 2,3,4,7,8 PCDF, 1,2,3,7,8 PCDD and 2,3,7,8 TCDD. This contamination pattern is similar to that found by Hsu et al. (2007) in the analysis of infant formulae commercialized in Taiwan and also similar to the contamination pattern of soybean infant formulae analyzed by Schecter et al. (1989). Schecter et al. (1989) also found a high percent of non detected congeners; besides, those present in higher concentrations were: OCDD > OCDF > 1,2,3,4,6,7,8-HpCDD > $1,2,3,4,6,7,8-\mathrm{HpCDF}$. Nonetheless, it is important to point out that in this work the higher concentration of those congeners with a high chlorination degree is also due to the fact that these compounds have a lower detection limit than those with less chlorine content.

The overall contamination of the infant formulae analyzed, expressed in $\mathrm{pg}$ WHO-TEQ $\mathrm{g}^{-1}$ fat and considering the medium bound value is shown in Table III. For comparative purposes, levels found in the analysis of similar products in other countries are also shown.

“[Insert Table III about here]”

PCDD/Fs concentrations calculated in this work, both with the lower and medium bound values, are higher in follow-on than in lactose-free formulae; these values are also higher than those observed in the initial formulae studied. However, the differences are not significant when results are calculated with the lower bound values. When this contamination is expressed with the medium bound values PCDD/Fs levels in the initial formulae analyzed are significantly lower $(\mathrm{p}<0,05)$ than those measured in the other two kind of samples studied. This difference has previously been found for 
ortho PCBs by the FSA UK (2004) in the analysis of this kind of food and it is explained by the different nutrients content.

As it can be seen in Table III, infant formulae contamination is similar to that reported for this kind of products in the UK (FSA UK, 2004) with values for the sum of PCDD/Fs and dioxin-like PCBs of 0.2-0.4 pg-TEQ $\mathrm{g}^{-1}$ fat and lower than those measured in infant formulae in Slovakia for the sum of PCDDs and PCDFs of $0.64 \mathrm{pg}$ WHO-TEQ $\mathrm{g}^{-1}$ fat (Chovancová et al. 2005) or the ones analyzed in Taiwan $(0.713 \pm$

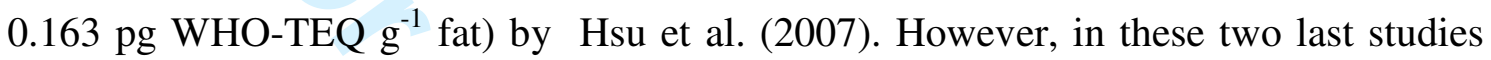
sample acquisition was carried out years before: in 2001 (Chovancová et al. 2005) and between 2000 and 2001 (Hsu et al. 2007). Besides, as these compounds accumulate in fatty tissues, levels found in the infant formulae analyzed are lower than the PCDD/Fs concentrations found in breast-milk samples. Therefore, concentrations of $7.77 \mathrm{pg}$ WHO-TEQ $\mathrm{g}^{-1}$ fat have been recently found in samples of breast-milk analyzed in Spain (Bordajandi et al. 2008). In addition, other studies on the levels of these pollutants in human milk carried out in Spain in recent years, have revealed concentrations which have declined from $11.82 \mathrm{pg}^{\mathrm{I}-\mathrm{TEQ}} \mathrm{g}^{-1}$ fat in samples collected in 1996 (Schuhmacher et al. 1999) to $9.1 \mathrm{pg} \mathrm{WHO-TEQ} \mathrm{g}^{-1}$ fat (Schuhmacher et al. 2004). The current levels of PCDD/Fs found in human milk samples in other countries, with values of $14.85 \mathrm{pg}$ WHO-TEQ $\mathrm{g}^{-1}$ fat in Japan (Guan et al. 2006); 14.7 pg WHO-TEQ $\mathrm{g}^{-1}$ fat in Taiwan (Hsu et al., 2007) or 29.4 pg WHO-TEQ $\mathrm{g}^{-1}$ fat in Belgium (Focant et al. 2002), are slightly higher than the results reported for Spanish breast milk samples and clearly higher than those found in formula milk samples.

The indicator PCB concentration in the samples analyzed is summarized in Table IV. Results are presented for the seven indicator congeners; the sum of all of them is also shown both in a fat and product basis. PCB concentration is below $1 \mathrm{ng} \mathrm{g}^{-1}$ fat for 
the three kinds of samples analyzed and the differences between them are not significant. These values are usually lower than those found in the literature for this kind of food. Schecter et al. (1989) analysed PCBs 28, 138, 153 and 180 in one soybean infant formula and found concentrations below detection limits ( $2 \mathrm{ng} \mathrm{g}^{-1}$ of lipids). Ramos et al. (1998) studied the presence of 15 congeners of PCBs in 8 soya based infant formulae collected in Spain. Levels found for the sum of the seven indicator PCBs were $7.36 \mathrm{ng} \mathrm{g}^{-1}$ fat. The indicator PCBs concentrations, as well as the analysis of PCDD/Fs, are much higher in breast milk samples than in infant formulae: $149.81 \mathrm{ng} \mathrm{g}^{-1}$ fat in Sweden (Glynn et al. 2001), $55.42 \mathrm{ng} \mathrm{g}^{-1}$ fat in Taiwan (Wang et al. 2004) or 108.3 $\mathrm{ng} \mathrm{g}^{-1}$ fat in Poland (Szyrwinska y Lulek, 2007).

"[Insert Table IV about here]"

The most frequently detected congeners are PCB 28 and 52 (86\% of the samples analyzed) have also been dominant in the three kind of samples analyzed. In fact, the average concentration of PCBs gets lower as the chlorination grade goes up from trichloro to heptachloro substituted congeners. This contamination pattern is similar to that of the soya based infant formulae analyzed in Spain by Ramos et al. (1998), where PCB 101, 28 and 77 are the most abundant congeners followed in this case by PCB 153, 138 and 180. This profile is usually different to that observed in cow or breast milk samples where the most abundant congeners are the highest chlorinated ones (Paumgartten et al. 2000; Glynn et al. 2001). However, it is important to take into account that mixtures of vegetable oils are added to these skimmed-milk based products in order to meet the nutrient requirements for children at this age. Unlike to animals, plants lack the ability to metabolise the lower chlorinated congeners and usually have PCB profiles different from other food categories (EFSA, 2005).

Assessment of dietary exposure is vital to obtain fundamental data concerning both food safety and trends in the intake of chemicals as well as to identify the sources of unusual 
residues. The estimated intake of PCDD/Fs and indicator PCBs in the two scenarios considered and calculated with the contamination of the samples previously described are depicted in Figure 2 (PCDD/Fs) and Figure 3 (PCBs). In these figures the estimated mean intake of these pollutants has been represented together with the 5 and 95 percentiles.

"[Insert Figure 2 about here]"

"[Insert Figure 3 about here]"

It is important to take into account that in scenario 1 , the highest PCDD/Fs and indicator PCBs intakes correspond to those children with a mean food intake and lower body weight (Percentile 5) whereas those children with a mean food intake and higher body weight (Percentile 95) have the lowest intake of these contaminants. However, in scenario 2, P 5 stand for those children with the lowest food consumption (Percentile 5) and mean body weight, and so the lowest PCDD/Fs and indicator PCBs intake and P 95 represents those children with the highest food consumption (Percentile 95) and mean body weight, and so the highest pollutants intake.

Estimated PCDD/Fs daily dietary intake during the first year of life due to the consumption of commercial infant formulae goes from $0.22 \mathrm{pg}$ WHO-TEQ $\mathrm{kg}^{-1}$ b.w. day $^{-1}$ to $0.56 \mathrm{pg}$ WHO-TEQ $\mathrm{kg}^{-1}$ b.w. day ${ }^{-1}$ in the first scenario and from $0.05 \mathrm{pg}$ WHOTEQ $\mathrm{kg}^{-1}$ b.w. day ${ }^{-1}$ to 0.65 pg WHO-TEQ $\mathrm{kg}^{-1}$ b.w. day ${ }^{-1}$ in the second one, when results are calculated with the lower bound values. The intake of indicator PCBs in children at this age goes from 0.92 to $2.32 \mathrm{ng} \mathrm{kg}^{-1}$ b.w. day ${ }^{-1}$ and from 0.20 to $2.69 \mathrm{ng}$ $\mathrm{kg}^{-1}$ b.w. day ${ }^{-1}$ in the first and second scenario respectively. These values go up to 0.611.93 pg WHO-TEQ $\mathrm{kg}^{-1}$ b.w. day ${ }^{-1}$ (scenario 1) and 0.13-2.08 pg WHO-TEQ kg-1 b.w. day $^{-1}$ (scenario 2) in the case of PCDD/Fs exposure when these estimations are calculated with the medium bound values of the infant formulae analyzed. In this case, 
indicator PCB children exposure reaches values of $0.97-2.43 \mathrm{ng} \mathrm{kg}^{-1}$ b.w. day ${ }^{-1}$ in the first scenario and from 0.21 to $2.82 \mathrm{ng} \mathrm{kg}^{-1}$ b.w. day ${ }^{-1}$ in the second one.

As it can be seen in Figures 2 and 3, mean exposures to PCDD/Fs and indicator PCBs are higher in the first scenario than in the second one. This is due to the fact that milk consumption quantities used in the first scenario are higher than those described in the DONALD study (Kersting et al. 1998), which is the reference used in the second situation. However, infant body weight data are very similar in the references used in both scenarios. Besides, in order to use the milk consumption quantities referred in the Euro-Growth study it was necessary to convert the values given in ml into grams of powdered infant formulae. Because of this transformation, the second scenario, where milk consumption quantities are given in grams of powdered infant formulae, is thought to provide a better estimation of these contaminant intakes. However, the highest and lowest PCDD/Fs and indicator PCBs intakes are found in the second scenario in which remarkable differences were observed between the different percentiles considered. In this case, P 95 and P 5 represent those children with a respectively higher and lower food intake than the average population but with the same body weight data. As important variations in food consumption quantities are observed between these two percentiles, so the estimated contaminant intakes also do. Though, it would be reasonable to think that the higher the food intake is, the more the body weight data increase. Since this circumstance has not been taken into account, it is possible that an underestimation (P 5) and an overestimation (P 95) of the estimated intake values have been produced when considering those extreme cases. Conversely, in the first scenario differences between the different percentiles considered are just due to the variations in the body weight which are not as significant as those mentioned for the second scenario. 
In all the cases girl's exposure to these compounds is higher than those observed in boys of the same age. This is only due to the fact that for the same food intake in both scenarios girls have a lower body weight than boys of the same age have. In addition, important differences are observed in these estimations when calculations are made with the lower or the medium values of the samples analyzed. These variations are higher in PCDD/Fs exposure than in those calculated for indicator PCBs. This is due to the higher L.O.D of the MS/MS methodology in relation to the HRMS methodology and the elevated percentage of non-detected congeners in the samples analyzed.

Although levels of these compounds are higher in follow-on than in infant formulae, a decrease of the estimated daily intake in the second semester of the year was observed in all cases. This is due to the lower food consumption of this kind of products in relation to the body weight as children get older. In most cases, the highest PCDD/Fs exposure for the mean population occurs in 3 month old babies while the highest indicator PCBs intake was observed in 6 month old babies. As far as we know, the introduction of complementary feeding, especially meat and dairy products, which occurs from 4-6 months, usually contributes in a higher proportion of the total dietary intake of these pollutants in children at these ages (Sasamoto et al. 2006; Weijs et al. 2006). This is why the decline with age observed in these intake estimations would not occur in a total diet study.

When children are fed with lactose-free formulae, an increase in PCDD/Fs and indicator PCBs exposure was observed particularly for 3 month old infants (Figure 4). In this case PCDD/Fs intakes for the average 3 month old population and with the lower bound values of the samples analyzed reach values up to $0.53 \mathrm{pg}$ WHO-TEQ $\mathrm{kg}^{-1}$ b.w. day $^{-1}$ and $0.58 \mathrm{pg}$ WHO-TEQ $\mathrm{kg}^{-1}$ b.w. day ${ }^{-1}$ for boys and girls respectively in the first scenario and 0.49 pg WHO-TEQ kg ${ }^{-1}$ b.w. day ${ }^{-1}$ and 0.54 pg WHO-TEQ kg ${ }^{-1}$ b.w. day ${ }^{-1}$ 
in the second. Indicator PCB exposure in children fed with lactose-free formulae also increase in 3 month old infants while an important decrease is observed in 6, 9 and 12 month old babies. This decrease is just due to the decline in the consumption of this product with age.

\section{"[Insert Figure 4 about here]"}

Similarly to our results, previous reports which have studied the PCDD/Fs exposure of non breast-fed children show regular intake levels in the range of the TDI of 1-4 pg WHO-TEQ $\mathrm{kg}^{-1}$ b.w. day ${ }^{-1}$ (WHO, 1998) and near to the TDI of 2 pg WHOTEQ $\mathrm{kg}^{-1}$ b.w. day ${ }^{-1}$ (SCF, 2001) as it can bee seen in the estimations calculated by Hsu et al. (2007) of $2.1 \mathrm{pg}$ WHO-TEQ $\mathrm{kg}^{-1}$ b.w. day ${ }^{-1}$ in one year old children. Lower exposure levels have been also seen in the UK with values varying between $<0.01$ and $0.3 \mathrm{pg}$ WHO-TEQ $\mathrm{kg}^{-1}$ b.w. day ${ }^{-1}$ in 6 month old babies and between $<0.01$ and $0.2 \mathrm{pg}$ WHO-TEQ kg ${ }^{-1}$ b.w. day ${ }^{-1}$ in 9 and 12 month old English children (FSA UK, 2004). Nonetheless, PCDD/Fs intakes by breast-fed infants, which usually have a higher exposure to these pollutants than non breast-fed children, habitually exceed the tolerable daily intake values. This can be seen in the results reported in previous works with exposure levels of 13 pg WHO-TEQ $\mathrm{kg}^{-1}$ b.w. day ${ }^{-1}$ (Hsu et al. 2007), 51 pg WHOTEQ kg ${ }^{-1}$ b.w. day ${ }^{-1}$ (Reis et al. 2002) or 76 pg WHO-TEQ kg ${ }^{-1}$ b.w. day ${ }^{-1}$ (Focant et al. 2002).

Regarding indicator PCBs intake, estimated exposure levels for breast-fed infants are also usually high. Considering $5 \mathrm{~kg}$ babies which consume $800 \mathrm{ml}$ of milk per day the intake of PCBs has been estimated in the European Union in $1249 \mathrm{ng} \mathrm{kg}^{-1}$ b.w. day $^{-1}$ (EFSA, 2005); in Poland they have calculated a lower intake with values of $364 \mathrm{ng} \mathrm{kg}^{-1}$ b.w. day ${ }^{-1}$ for the first breast-fed infants and $375 \mathrm{ng} \mathrm{kg}^{-1}$ b.w. day ${ }^{-1}$ for the second (Szyrwińska and Lulek, 2007). These values are both higher than those 
estimated in this work for non-breast fed children and higher than the TDI of $10 \mathrm{ng} \mathrm{kg}^{-1}$ b.w. day ${ }^{-1}$, value proposed by the Dutch National Institute of Health and Environment (RIVM), for the sum of the seven indicator PCBs (Baars et al. 2001). We should consider that since this Maximum Permissible Risk level (MPR) was estimated on the basis of an experiment with a commercial PCB mixture it has to be appreciated as provisional and limited in its applicability (Bakker et al. 2003). As far as we know, there are no studies estimating indicator PCBs exposure for children at this age fed with commercial infant formulae but, in any case, these exposures are expected to be similar to our results and lower than those observed in breast fed children.

The fact that the highest PCDD/Fs and PCBs human exposure occurs in infants via breast-feeding has been indicated by several authors (Guan et al. 2006; Szyrwińska and Lulek, 2007) who think this fact is due to the elevated concentrations of these compounds in breast milk together with the higher food consumption in relation to body weight. As a consequence and due to the dioxins and PCBs bioaccumulation capability the accumulated doses of these contaminants are also higher in breast fed children. Patandin et al. (1999) found that breast feeding during a period of six months increases the PCDD/Fs and PCBs TEQ body burden by $12 \%$ in boys and $14 \%$ in girls until the age of 25 years. However, evidence for the health advantages of breastfeeding and recommendations for practice have continued to increase over the past decades. Breast feeding provides all the energy and nutrients that the infant needs for the first months of life, promotes sensory and cognitive development, protects the infant against infectious and chronic diseases and reduces infant mortality due to common childhood illnesses (León-Cava et al. 2002; Horta et al. 2007). Consequently, despite the presence of PCDD/Fs and PCBs in breast milk and the risk those contaminants pose to the nursing infant WHO supports and encourages breast-feeding due to their demonstrated benefits. 


\section{Conclusions}

Levels of PCDD/Fs and indicator PCBs in the samples of infant formulae analyzed are low and similar to those found in the analysis of this kind of food in other countries, but yet they are lower than the levels found in breast-milk samples. Moreover, PCDD/Fs content is in all cases below the maximum limits established for the EU for the presence of these contaminants in dairy products. Estimated mean daily intake of PCDD/Fs and indicator PCBs as calculated in this work shows that exposure to these contaminants through the consumption of infant formulae is also low and below the tolerable daily intake values for the exposure to these contaminants. Although consumption of infant formulae is not supposed to be a risk due to the low levels of these contaminants found in this study, Health Departments, WHO and FSA encourage breastfeeding for the overall health and development of the infant on the basis of the convincing evidence. However the introduction of complementary feeding can increase this exposure to significant values. Furthermore, the observed differences between the diverse scenarios and percentiles studied show the importance of data selection when estimating exposure to chemicals. In fact, it is essential to know the uncertainties concerning intake estimation. In order to improve this situation it is necessary to publish guides collecting data about the food consumption of the infant population similar to those published by the Spanish government and the European Union regarding the consumption of food items of the average population.

\section{Acknowledgements}

This work has been supported by the Spanish Ministry of Science and Technology (Project AGL 2001-2533) and Gobierno de Aragón (Group A01/2003-2008). Author S. 
Lorán was supported by a doctoral fellowship from the Spanish Ministry of Science and Technology (FP 2001-2727).

\section{References}

Baars AJ, Theelen RMC, Janssen PJCM, Hesse JM, Van Apeldoorn ME, Meijerink MCM, Verdam L, Zeilmaker, MJ. 2001. Re-evaluation of human toxicological maximum permissible risk levels. Report no. 711701025, National Institute of Public Health and the Environment (RIVM), Bilthoven, The Netherlands.

Baars AJ, Bakker MI, Baumann RA, Boon, PE, Freijer JI, Hoogenboom LAP, Hoogerbrugge R, van Klaveren JD, Kiem AKD, Traag WA, de Vries J. 2004. Dioxins, dioxin-like PCBs and non-dioxin-like PCBs in foodstuffs: occurrence and dietary intake in The Netherlands. Toxicology Letters 151: 51-61.

Bakker MI, Baars AJ, Baumann RA, Boon PE, Hoogerbrugge R. 2003. Indicator PCBs in foodstuffs: occurrence and dietary intake in The Netherlands at the end of the $20^{\text {th }}$ century. RIVM report no. 639102025/2003. National Institute of Public Health and the Environment (RIVM), Bilthoven, The Netherlands.

Bocio A, Domingo JL, Falcó G, Llobet JM. 2007. Concentrations of PCDD/PCDFs and PCBs in fish and seafood from the Catalan (Spain) market: Estimated human intake. Environment International 33: 170-175.

Bordajandi LR, Martín I, Abad E, Rivera J, González MJ. 2006. Organochlorine compounds (PCBs, PCDDs and PCDFs) in seafish and seafood from the Spanish Atlantic Southwest Coast. Chemosphere 64: 1450-1457.

Bordajandi LR, Abad E, González MJ. 2008. Occurrence of PCBs, PCDD/Fs, PBDEs and DDTs in Spanish breast milk: Enantiomeric fraction of chiral PCBs. Chemosphere 70: 567-575. 
Bueno M, Sarría A, Pérez-González, JM. 2006. Nutrición en Pediatría. $3^{\text {erd }}$ edition. Madrid, (España): Ergon.

Egan H, Kirk RS, Sawyer R, 1981. Pearson's Chemical Analysis of Foods. 8 th Ed. Essex, England.

Chovancová J, Kočan A, Jursa S. 2005. PCDDs, PCDFs and dioxin-like PCBs in food of animal origin (Slovakia). Chemosphere 61: 1305-1311.

European Commission (EC), 2002. Commission Decision of 12 August 2002 implementing Council Directive 96/23/EC concerning the performance of analytical methods and the interpretation of results. OJEC L221/8-36.

European Commission (EC), 2006. Commission regulation (EC) No. 1881/2006 of 19 December 2006 setting maximum levels for certain contaminants in foodstuffs. OJEC L364/5-24.

European Food Safety Authority (EFSA). 2005. Opinion of the scientific panel on contaminants in the food chain on a request from the commission related to the presence of non-dioxin-like Polychlorinated Biphenyls (PCB) in feed and food (Question No EFSA-Q-2003-114). Adopted on 8 November 2005. The EFSA Journal 284: 1-137.

Fernández MA, Gómara B, Bordajandi LR, Herrero L, Abad E, Abalos M, Rivera J, González MJ. 2004. Dietary intakes of polychlorinated dibenzo-p-dioxins, dibenzofurans and dioxinlike polychlorinated biphenyls in Spain. Food Additives and Contaminants 21(10): 983-991.

Focant JF, Pirard C, Thielen C, De Pauw E. 2002. Levels and profiles of PCDDs, PCDFs and cPCBs in Belgian breast milk. Estimation of infant intake. Chemosphere 48: 763-770. 
Food Standards Agency UK, (FSA, UK). 2004. Dioxin and Dioxin-like PCBs in Infant Formulae. Food Survey Information Sheet 49/04. Available: http://www.food.gov.uk/multimedia/pdfs/fsis6004.pdf

Franch MA, Bedate Calderón P, Calvo Romero C. 2001. Recomendaciones de ingesta durante el primer año de vida. Anales Españoles de Pediatría 54 (2): 153-156.

Freeman V, van't Hof M, Haschke F, Euro-Growh Study Group. 2000. Patterns of Milk and Food Intake in Infants from Birth to Age 36 Months: The Euro-Growth Study. Journal of Pediatric Gastroenterology and Nutrition 31 (SSp 1 July): S76-S85.

Glynn AW, Atuma S, Aune M, Darnerud PO, Cnattingius S. 2001. Polychlorinated Biphenyl Congeners as Markers of Toxic Equivalents of Polychlorinated Biphenyls, Dibenzo-p-dioxins and Dibenzofurans in Breast Milk. Environmental Research 86 (3): 217-228.

Gómara B, Bordajandi LR, Fernández MA, Herrero L, Abad E, Abalos M, Rivera J, González, MJ. 2005. Levels and trends of polychlorinated dibenzo-pdioxins/furans (PCDD/Fs) and dioxin-like polychlorinated biphenyls (PCBs) in Spanish commercial fish and shellfish products, 1995-2003. Journal of Agricultural and Food Chemistry 53(21): 8406-8413.

Guan P, Tajimi M, Uehara R, Watanabe M, Oki I, Ojima T, Nakamura Y. 2006. Congener profiles of PCDDs, PCDFs, and dioxin-like PCBs in the breast milk samples in Tokyo, Japan. Chemosphere 62: 1161-1166.

Haschke F, Vant't Hof M. 2000. Foreword. Journal of Pediatric Gastroenterology and Nutrition, 31 (SSp 1July ): S1-S2

Haschke F, van't Hof MA, the Euro-Growth Study Group. 2000a. Euro-Growth References for Breast-Fed Boys and Girls: Influence of Breast-Feeding and Solids on Growth Until 36 Months of Age. Journal of Pediatric Gastroenterology and Nutrition 31 (SSp 1July): S60-S71. 
Haschke F, van't Hof MA, Euro-Growth Study Group. 2000b. Euro-Growth References for Length, Weight, and Body Circumferences. Journal of Pediatric Gastroenterology and Nutrition 31 (SSp 1July): S14-S38.

Horta BL, Bahl R, Martines J, Victora C. Evidence on the long-term effects of breastfeeding: systematic reviews and meta-analyses. Geneva: World Health Organization, 2007.

Hsu JF, Guo YL, Liu CH, Hu SC, Wang JN, Liao PC. 2007. A comparison of PCDD/PCDFs exposure in infants via formula milk or breast milk feeding. Chemosphere 66: 311-319.

Joint FAO/WHO Expert Committee on Food Additives (JECFA). 2002. Safety Evaluation of Certain Food Additives and Contaminants. Polychlorinated dibenzodioxins, Polychlorinated dibenzofurans, and coplanar Polychlorinated biphenyls. WHO Food Additives Series 48. Available: http://www.fao.org/es/ESN/Jecfa/57corr.pdf

Kersting M, Alexy U, Sichert-Hellert W, Manz F, Schöch G. 1998. Measured consumption of commercial infant food products in German infants: results from the DONALD study. Journal of Pediatric Gastroenterology and Nutrition 27: 547-552.

Lázaro R, Bayarri S, Herrera A, Conchello P, Ariño A, Yagüe C, Pérez, C. 2002. Estimated dietary intake of polychlorinated biphenyls and organochlorine pesticides from Aragonese (NE Spain) diet. Organohalogen Compounds 55: 323-326.

León-Cava N, Lutter C, Ross J, Martin L.Quantifying the benefits of breastfeeding: a summary of the evidence. Washington DC: Pan American Health Organization, 2002. 
Llobet JM, Martí-Cid R, Castell V, Domingo JL. 2008. Significant decreasing trend in human dietary exposure to PCDD/PCDFs and PCBs in Catalonia, Spain. Toxicology Letters 178: 117-126.

Lorán S, Bayarri S, Conchello P, Herrera A. 2007. Evaluation of GC-ion trap-MS/MS methodology for monitoring PCDD/Fs in infant formulas. Chemosphere, $67,513-520$.

Patandin S, Dagnelie PC, Mulder PGH, Op de Coul E, van der Veen JE, Weisglas-Kuperus N, Sauer, PJJ. 1999. Dietary exposure to polychlorinated biphenyls and dioxins from infancy until adulthood: a comparison between breast-feeding, toddler, and long-term exposure. Environmental Health Perspectives 107 (1): 45-52.

Paumgartten FJR, Cruz CM, Chahoud I, Palavinskas R, Mathar W. 2000. PCDDs, PCDFs, PCBs and other organochlorine compounds in human milk from Rio de Janeiro, Brazil. Environmental Research 83(3): 293-297.

Ramos L, Torre M, Laborda F, Marina ML. 1998. Determination of polychlorinated biphenyls in soybean infant formulas by gas chromatography. Journal of Chromatography A 823: 365-372.

Reis M.F, Miguel JMP, Pisarra MI, Sampaio C, Calheiros J. 2002. Infant exposure to $\mathrm{PCDD} / \mathrm{Fs}$ in Portugal: first results from an environmental health survey program near Lisbon. Organohalogen Compounds 55: 247-249.

Sasamoto T, Tabebe H, Hashimoto T, Ushio F, Ibe A. 2006. Estimation of daily intake of PCDDs, PCDFs and Co-PCBs from baby foods. Absract. Shokuhin Eiseigaku Zasshi 47 (4): 157-163.

Schecter A, Fürst P, Fürst C, Meemken HA, Groebel W, Vu DQ. 1989. Levels of polychlorinated dibenzodioxins and dibenzofurans in cow's milk and in soy bean 
derived infant formulas sold in the United States and other countries. Chemosphere 19 (1-6): 913-918.

Schuhmacher M, Domingo JL, Llobet JM, Kiviranta H, Vartiainen T. 1999. PCDD/F concentrations in milk of nonoccupationally exposed women living in southern Catalonia, Spain. Chemosphere 38: 995-1004.

Schuhmacher M, Domingo JL, Kiviranta H, Vartiainen T. 2004. Monitoring dioxins and furans in a population living near a hazardous waste incinerator: levels in breast milk. Chemosphere 57: 43-49.

Scientific Committee on Food (SCF). 2001. Opinion of the Scientific Committee on Food on the risk assessment of dioxins and dioxin-like PCBs in food (update based on new scientific information available since the adoption of the SCF opinion of 22 November 2000) (adopted by the SCF on 30 May 2001). CS/CNTM/DIOXIN/20 final. Available: http://ec.europa.eu/food/fs/sc/scf/out90_en.pdf.

Szyrwińska K, Lulek J. 2007. Exposure to specific polychlorinated biphenyls and some chlorinated pesticides via breast milk in Poland. Chemosphere 66: 1895-1903.

Tard A, Gallotti S, Leblanc JC, Volatier JL. 2007. Dioxins, furans and dioxinlike PCBs: Occurrence in food and dietary intake in France. Food Additives and Contaminants 24: 1007-1017.

van den Berg M, Birnbaum L, Bosveld ATC, Brunström B, Cook P, Feeley M, Giesy JP, Hanberg A, Hasegawa R, Kennedy SW, Kubiak T, Larsen JC, van Leeuwen FXR, Liem AKD, Nolt C, Peterson RE, Poellinger L, Safe S, Schrenk D, Tillitt D, Tysklind M, Younes M, Wærn F, Zacharewski T. 1998. Toxic Equivalency Factors (TEFs) for PCBs, PCDDs, PCDFs for Humans and Wildlife. Environmental Health Perspectives 106 (12): 775-792. 
van't Hof MA, Haschke F, Euro-Growth Study Group. 2000. The Euro-Growth Study: Why, Who, and How. Journal of Pediatric Gastroenterology and Nutrition 31 (SSp 1July): S3-S13.

Wang SL, Lin CY, Guo YL, Lin LY, Chou, WL, Chang LW 2004. Infant exposure to polychlorinated dibenzo-p-dioxins, dibenzofurans and biphenyls (PCDD/Fs, PCBs)-correlation between prenatal and postnatal exposure. Chemosphere 54: 14591473.

Weijs PMJ, Bakker MI, Korver KR, van Goor Ghanaviztchi K, van Wijnen JH. 2006. Dioxin and dioxin-like PCB exposure of non-breastfed Dutch infants. Chemosphere 64: 1521-1525.

World Health Organization, (WHO). 1998. Executive summary: Assessment of the health risk of dioxins: reevaluation of the Tolerable Daily Intake (TDI). WHO Consultation, May 25-29, 1998, Geneva, Switzerland. 
Table I. References of milk consumption quantities and body weight data used in the Scenario 1 obtained from the Euro-Growth Study (Freeman et al. 2000; Haschke et al. 2000b)

\begin{tabular}{|c|c|c|c|c|c|c|c|}
\hline \multirow{3}{*}{$\begin{array}{c}\text { Age } \\
\text { (months) }\end{array}$} & \multirow{3}{*}{$\begin{array}{l}\text { Infant formulae } \\
\text { intake }(\mathrm{ml})\end{array}$} & \multicolumn{6}{|c|}{ Body weight (kg) } \\
\hline & & \multicolumn{2}{|c|}{ P 5} & \multicolumn{2}{|c|}{ Mean } & \multicolumn{2}{|c|}{ P 95 } \\
\hline & & Boys & Girls & Boys & Girls & Boys & Girls \\
\hline 3 & 841 & 5.143 & 4.817 & 6.216 & 5.708 & 7.340 & 6.752 \\
\hline 6 & 626 & 6.701 & 6.310 & 8.051 & 7.491 & 9.477 & 8.911 \\
\hline 9 & 500 & 7.715 & 7.194 & 9.284 & 8.677 & 11.003 & 10.444 \\
\hline 12 & 485 & 8.586 & 8.023 & 10.268 & 9.648 & 12.196 & 11.616 \\
\hline
\end{tabular}


Table II. References of milk consumption quantities and body weight data used in the scenario 2 obtained from the DONALD Study (Kersting et al. 1998)

\begin{tabular}{cccccc}
\hline \multirow{2}{*}{$\begin{array}{c}\text { Age } \\
\text { (months) }\end{array}$} & \multicolumn{2}{c}{$\begin{array}{c}\text { Infant formulae intake } \\
\text { (g of dry wet) }\end{array}$} & \multicolumn{2}{c}{ Body weight $(\mathrm{kg})$} \\
\cline { 2 - 6 } & P 5 & Mean & P 95 & Boys & Girls \\
\hline 3 & 38.4 & 105.3 & 143.9 & 6.4 & 5.8 \\
6 & 22.1 & 67.1 & 124.6 & 8.1 & 7.5 \\
9 & 17.6 & 46.8 & 90.2 & 9.3 & 8.6 \\
12 & 12.9 & 44.9 & 90.4 & 10.3 & 9.4 \\
\hline
\end{tabular}


Table III. PCDD/Fs (pg WHO-TEQ $\mathrm{g}^{-1}$ fat) concentration in the infant formulae analyzed in this work and in samples analyzed in other countries.

\begin{tabular}{|l|c|c|c|c|}
\hline Country & No. of samples & PCDD/Fs & $\begin{array}{c}\text { Year of } \\
\text { collection }\end{array}$ & Reference \\
\hline Brazil & 4 & $0.22-0.45^{*}$ & 1998 & $\begin{array}{c}\text { Päpke and } \\
\text { Tritscher, 2000. }\end{array}$ \\
\hline UK & 96 & $0.2-0.4^{* *}$ & 2003 & FSA UK, 2004 \\
\hline Slovakia & 4 & 0.64 & 2001 & $\begin{array}{c}\text { Chovancová et } \\
\text { al. 2005 }\end{array}$ \\
\hline Taiwan & 10 & 0.71 & $2000-2001$ & Hsu et al. 2007. \\
\hline \multirow{3}{*}{ Spain } & 5 (Initial formula) & 0.30 & & This study \\
\cline { 2 - 3 } & $\begin{array}{c}5 \text { (Follow-on } \\
\text { formula) }\end{array}$ & 0.46 & \multirow{2}{*}{$2004-2005$} & \\
\cline { 2 - 3 } & $\begin{array}{c}\text { (Lactose-free } \\
\text { formula) }\end{array}$ & 0.43 & & \\
\hline
\end{tabular}

* pg I-TEQ g ${ }^{-1}$ fat

** Sum of PCDD/Fs and dioxin-like PCBs 
Table IV. Indicator PCBs in samples of infant formulae analyzed in this study.

\begin{tabular}{|c|c|c|c|c|c|c|}
\hline \multirow[b]{2}{*}{ PCB } & \multicolumn{2}{|c|}{$\begin{array}{c}\text { Initial }(\mathrm{n}=5) \\
\left(\text { ng g }^{-1} \text { fat }\right)\end{array}$} & \multicolumn{2}{|c|}{$\begin{array}{c}\text { Follow-on }(\mathrm{n}=5) \\
\left(\text { ng g }^{-1} \text { fat }\right)\end{array}$} & \multicolumn{2}{|c|}{$\begin{array}{c}\text { Lactose-free }(n=4) \\
\left(\mathrm{ng} \mathrm{g}^{-1} \text { fat }\right)\end{array}$} \\
\hline & $\begin{array}{l}\text { Lower } \\
\text { bound }\end{array}$ & $\begin{array}{l}\text { Medium } \\
\text { bound }\end{array}$ & $\begin{array}{l}\text { Lower } \\
\text { bound }\end{array}$ & $\begin{array}{c}\text { Medium } \\
\text { bound }\end{array}$ & $\begin{array}{l}\text { Lower } \\
\text { bound }\end{array}$ & $\begin{array}{c}\text { Medium } \\
\text { bound }\end{array}$ \\
\hline 28 & 0.17 & 0.17 & 0.53 & 0.53 & 0.35 & 0.35 \\
\hline 52 & 0.05 & 0.05 & 0.09 & 0.09 & 0.06 & 0.06 \\
\hline 101 & 0.01 & 0.02 & 0.02 & 0.02 & 0.01 & 0.01 \\
\hline 118 & 0.01 & 0.02 & 0.03 & 0.04 & n.d. & 0.01 \\
\hline 153 & n.d. & 0.01 & n.d. & 0.01 & n.d. & 0.01 \\
\hline 138 & n.d. & 0.01 & 0.01 & 0.02 & n.d. & 0.01 \\
\hline 180 & n.d. & 0.01 & 0.01 & 0.02 & 0.01 & 0.01 \\
\hline \multicolumn{7}{|l|}{ TOTAL } \\
\hline $\begin{array}{l}\Sigma \text { PCBs ngg }^{-1} \\
\text { fat }\end{array}$ & 0.23 & 0.29 & 0.70 & 0.73 & 0.42 & 0.46 \\
\hline $\begin{array}{l}\Sigma \text { PCBs ng g }{ }^{-1} \\
\text { product }\end{array}$ & 0.06 & 0.08 & 0.16 & 0.17 & 0.12 & 0.13 \\
\hline
\end{tabular}


Figure 1. Contamination pattern of the three kind of infant formulae analyzed. White bar represents follow-on formula. Grey bar represents lactose-free formula. Black bar represents initial formula.

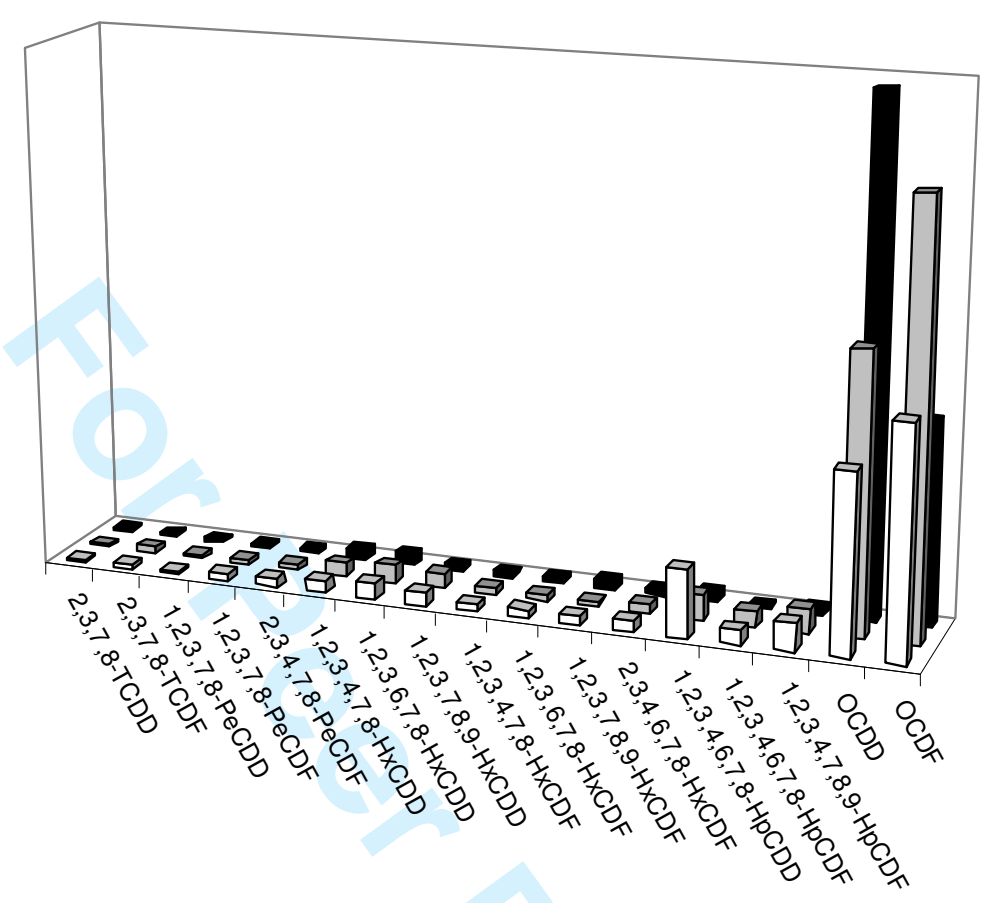


Figure 2. Estimated intake of PCDD/Fs (pg WHO-TEQ/ $\mathrm{kg}^{-1}$ b.w. day ${ }^{-1}$ ) in children up to one year of age through the consumption of infant formulae calculated with the lower (A) and medium (B) bound values of the samples analyzed. Whiskers above and below the mean value indicate the 5 th and 95 th percentiles.

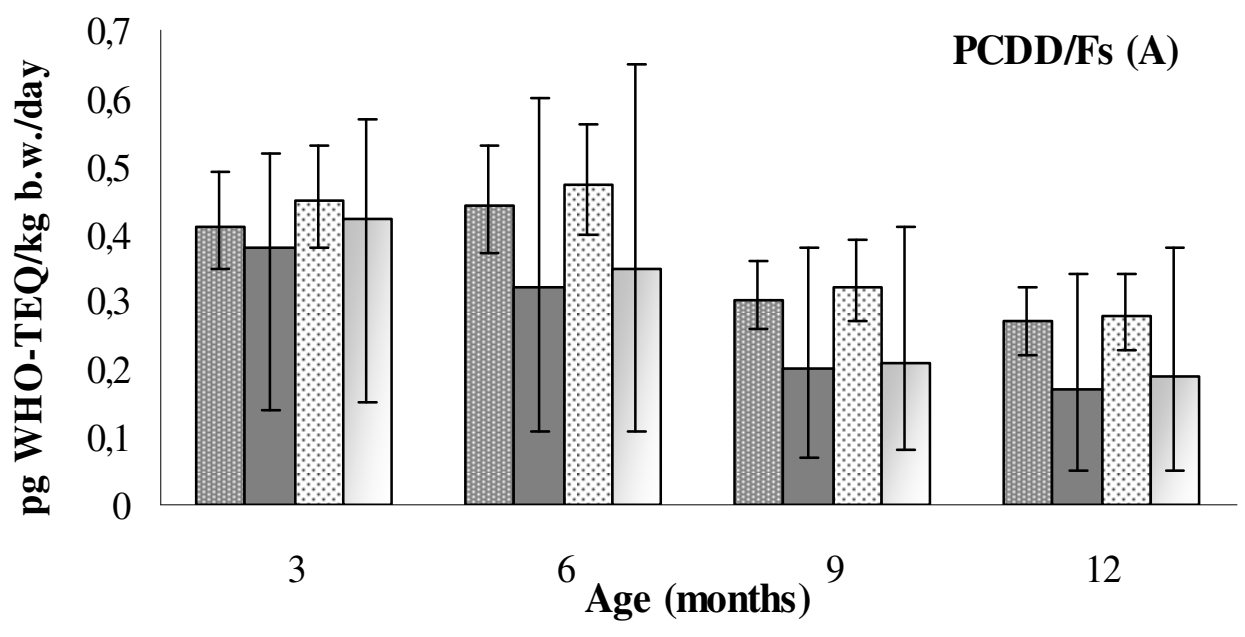

$\square$ Boys (Scen. 1) $\square$ Boys (Scen. 2) $⿴ 囗 十)$ Girls (Scen. 1) $\square$ Girls (Scen. 2)

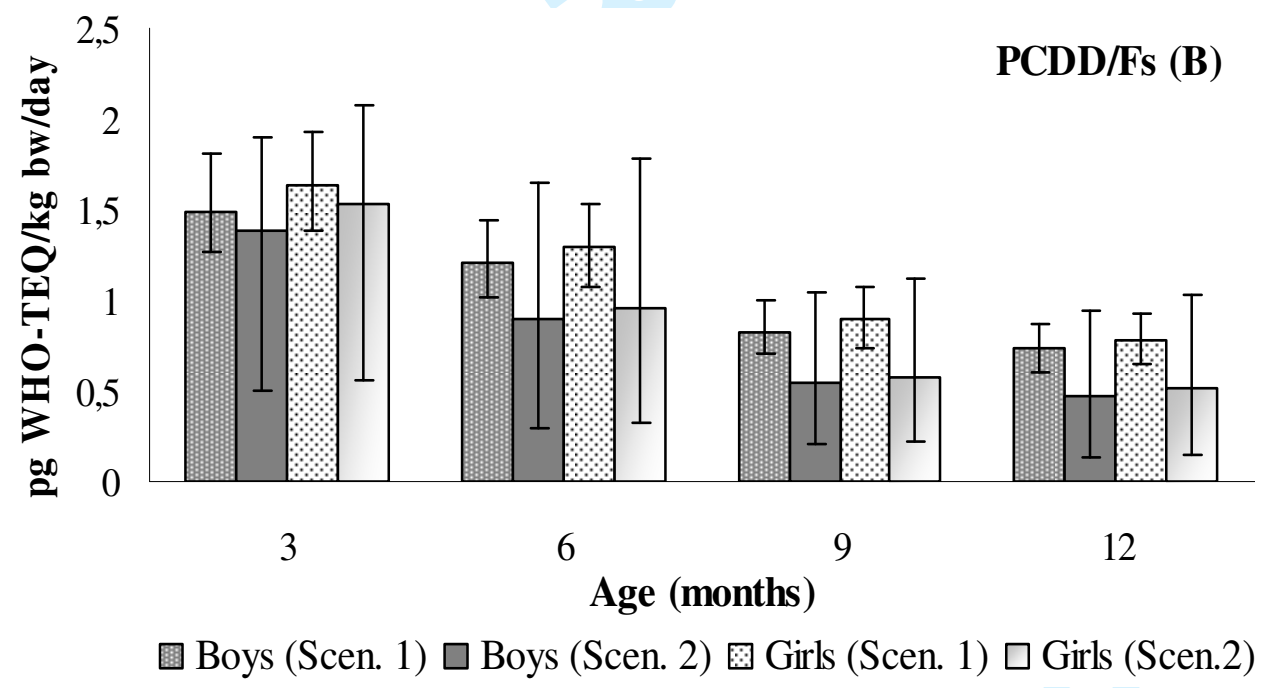


Figure 3. Estimated intake of PCB (ng/ $\mathrm{kg}^{-1}$ b.w. day $\left.{ }^{-1}\right)$ in children up to one year of age through the consumption of infant formulae calculated with the lower (A) and medium (B) bound values of the samples analyzed. Whiskers above and below the mean value indicate the 5 th and 95 th percentiles.

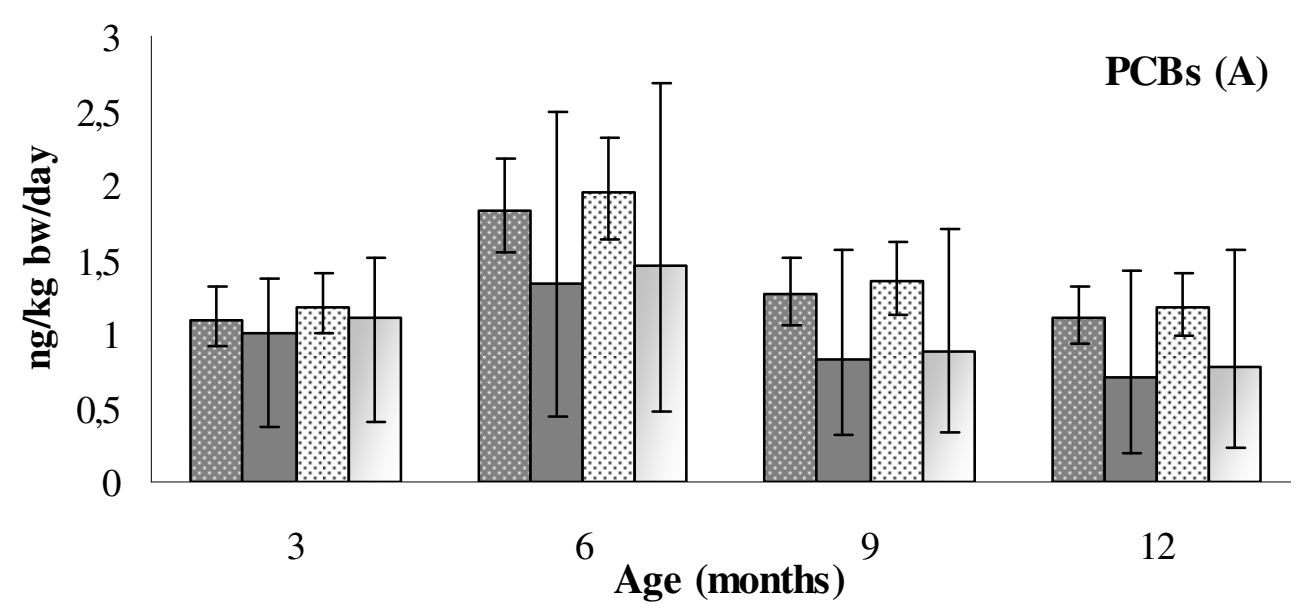

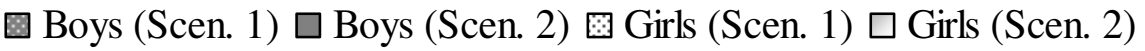

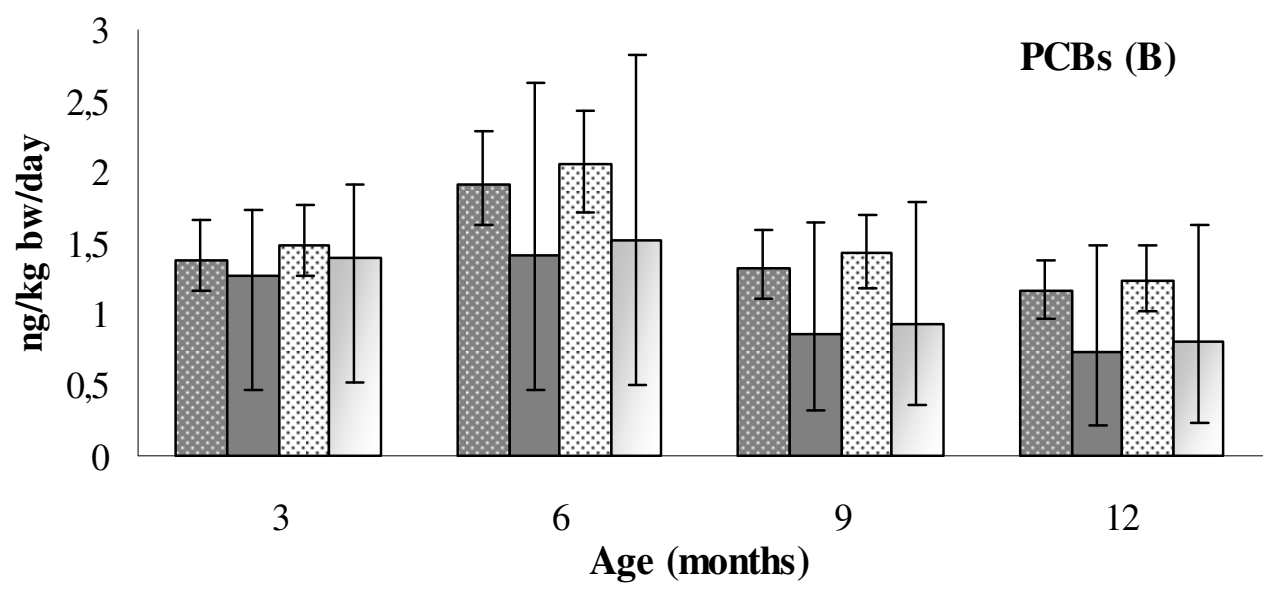

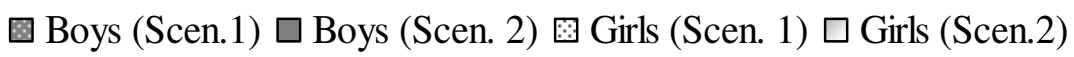


Figure 4. Estimated intake of PCDD/Fs (pg WHO-TEQ/ kg ${ }^{-1}$ b.w. day ${ }^{-1}$ ) and indicator $\mathrm{PCB}\left(\mathrm{ng} / \mathrm{kg}^{-1}\right.$ b.w. day $\left.{ }^{-1}\right)$ in children up to one year of age through the consumption of lactose-free infant formulae calculated with the lower (A) and medium (B) bound values of the samples analyzed. Whiskers above and below the mean value indicate the 5 th and 95th percentiles.
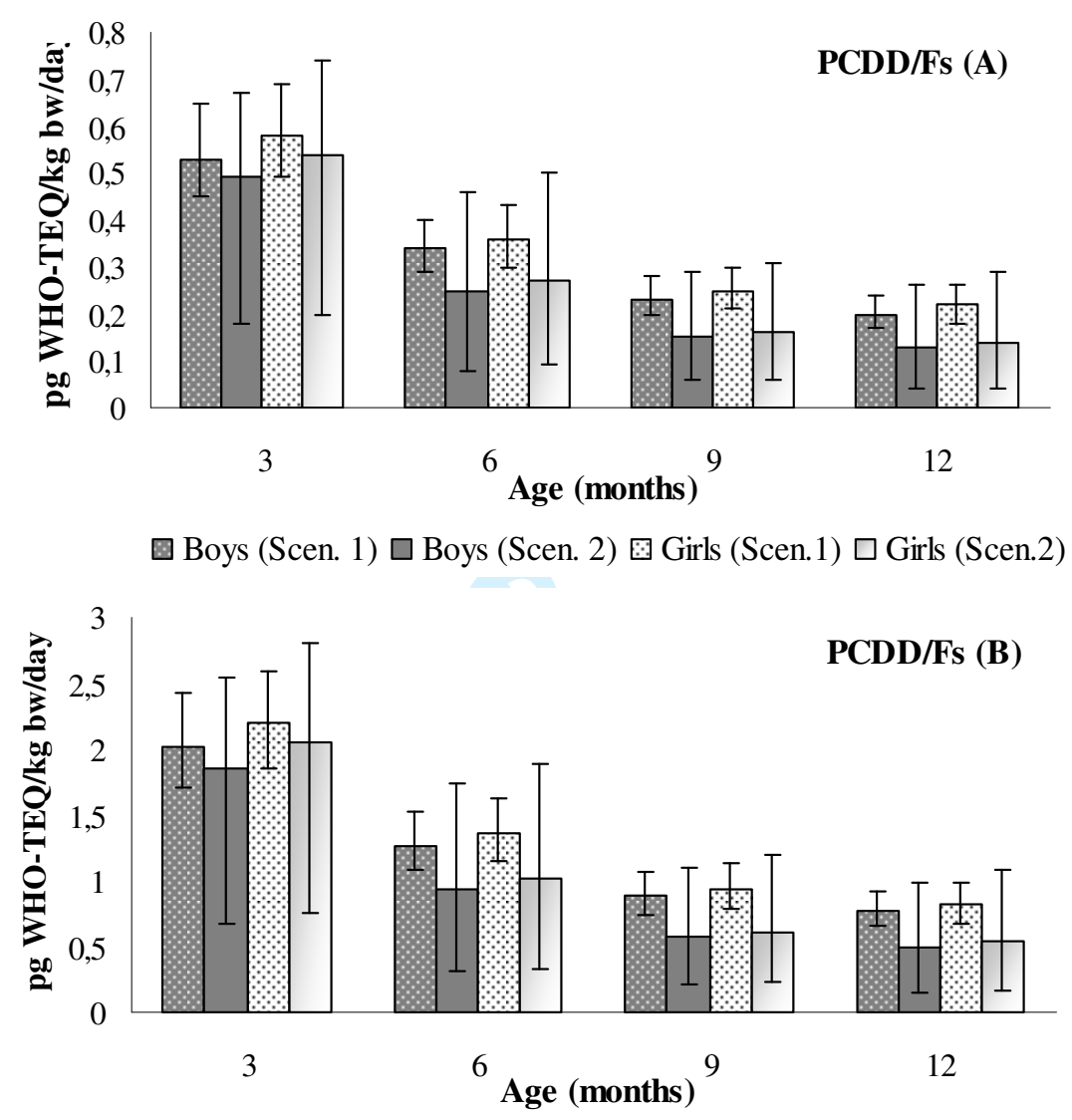

回 Boys (Scen.1) $\square$ Boys (Scen. 2) $⿴$ Girls (Scen. 1) $\square$ Girls (Scen.2)

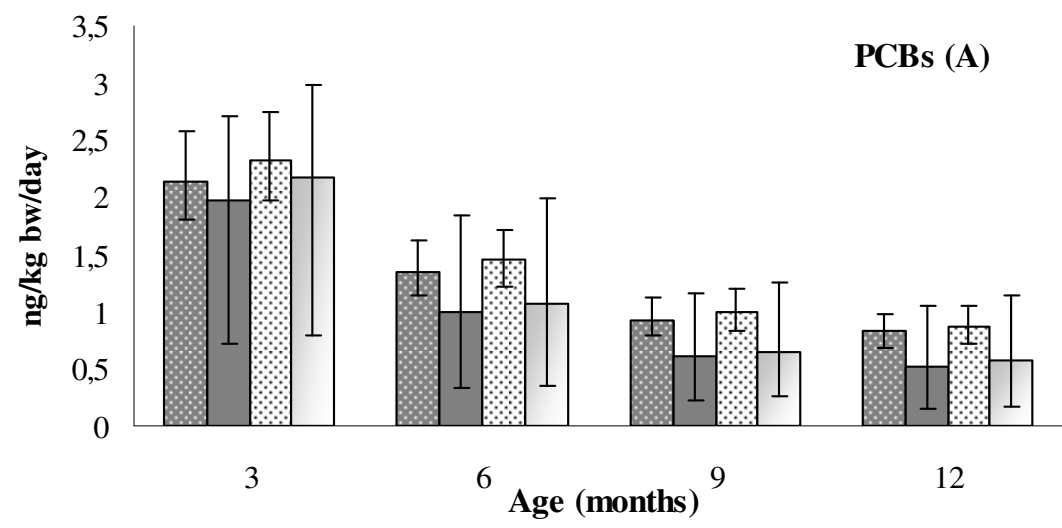

$\square$ Boys (Scen. 1) $\square$ Boys (Scen. 2) $⿴ 囗$ Girls (Scen. 1) $\square$ Girls (Scen. 2)

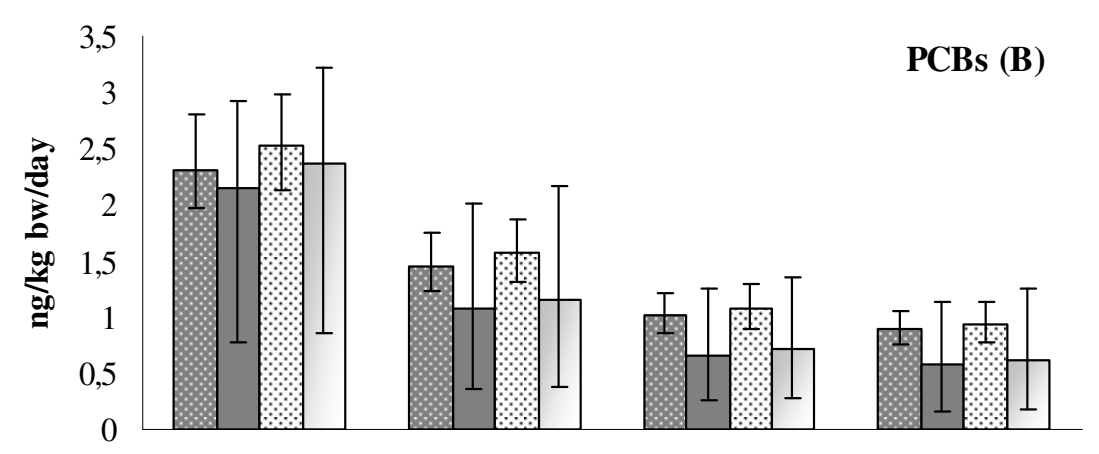

Rెttp://mc.manu'ssgiptsfentrant).Com/tfac Emall: fac@tandf.co.uk

$\square$ Boys (Scen. 1) $\square$ Boys (Scen. 2) $⿴ 囗 大)$ Girls (Scen.1) $\square$ Girls (Scen.2) 